\title{
THE DETERMINANTS OF SYSTEMIC RISK: EVIDENCE FROM INDONESIAN COMMERCIAL BANKS
}

\author{
Mutiara Aini*, Deddy Priatmodjo Koesrindartoto** \\ Mutiara Aini*, Deddy Priatmodjo Koesrindartoto** \\ *Corresponding Author, School of Business and Management, Bandung Institute of Technology, Bandung, \\ Indonesia. Email: mutiara_aini@sbm-itb.ac.id \\ **School of Business and Management, Bandung Institute of Technology, Bandung, Indonesia
}

\begin{abstract}
This paper examines the determinants of systemic risk across Indonesian commercial banks using quarterly data from 2001Q4 to 2017Q4. Employing four measures of systemic risk, namely value-at-risk (VaR), historical marginal expected shortfall (MESH), marginal expected shortfall from GARCH-DCC (MESdcc), and long-run marginal expected shortfall (LRMES), we find that bank size is positively related to systemic risk, whereas banks and economic loan activity are negatively related to systemic risk. These findings suggest that the government needs to regulate loan activities and to monitor big banks as they have significant impacts on bank systemic risk.
\end{abstract}

Keywords: Bank fragility; Bank performance; Financial regulation; Systemic risk.

JEL Classifications: G01; G21; G28.

Article history:

Received : June 21, 2019

Revised : September 15, 2019

Accepted : February 24, 2020

Available online : February 28, 2020

https://doi.org/10.21098/bemp.v23i1.1293 


\section{INTRODUCTION}

The Indonesian banking sector plays a key role in the country's financial system and economy. In 2017, banking sector assets represented about 70\% of the total assets of Indonesia's financial sector. The global financial crises of 1997/1998 and 2008 significantly impacted Indonesia. For example, the global financial crisis of 1997/1998 caused collapse of several Indonesian banks and the banking sector's capital ratio to fall sharply to $-16 \%$. In response, the central bank (Bank Indonesia) maintained financial stability by regulating the banking system through monetary policy. Besides, this banking sector condition urged Bank Indonesia to improve liquidity and to maintain stability of the financial system through capital injections. With regard to the global financial crisis of 2008, the Financial System Stability Committee decided to shore up the solvency of Bank Century by giving it a large fund in order to prevent a systemic crisis. This undertaking was controversial in Indonesia, with critics questioning whether the central bank's action was necessary since the cost was too expensive.

In response to the crisis of 2008, the central bank applied Basel II in order to improve supervision and to improve the banks' condition in Indonesia. This action led to an increase in Capital Adequacy Ratio (CAR) level to 20\% in 2015. Basel agreements are used as the basis of the micro-prudential regulatory framework in Indonesia and several other countries. ${ }^{1}$ Later in 2011, the government established a financial supervisor called Financial Service Authority (FSA). The purpose of this establishment is to redistribute the supervisory powers of the central bank, whereby the central bank is in charge of managing systemic risk through macroprudential regulation, while the FSA focuses on idiosyncratic risk through microprudential regulation. In other words, the primary purpose of the two institutions is to mitigate both systemic and idiosyncratic risk in times of crises.

Systemic risk is the risk of instability faced by an individual institution that can trigger instability in other institutions, the financial system or even the overall economy due to the interaction between institutions. The main focus of systemic risk is that when an institution is in distress, it will create panic in the financial system and cause other institutions to fail, which may eventually lead to a financial crisis. Distress in one bank can propagate and distress other banks because systemic risk affects any system whose components are interconnected. There are some paradigms in the discussion of systemic risk, including too-big-tofail (TBTF) and too-interconnected-to-fail (TITF) (Benoit, Colliard, Hurlin, \& Pe, 2017; Huang, Zhou, \& Zhu, 2011; Zhou, 2010). The discussion of TBTF centres on a condition whereby the institution in distress is large, and, hence, suggests that size is an important variable (Adrian \& Brunnermeier, 2016). While TITF focuses on how systemically important an institution is when it is connected to several institutions; hence, connectedness is an important variable in systemic risk (Chan-Lau, 2010; Drehmann \& Tarashev, 2013). Distress or failure in a banking system could trigger an economy-wide crisis, if unresolved quickly. As a financial

${ }^{1}$ Basel I and Basel II agreements impose minimum capital requirement as a preventive tool against the unexpected losses (Pillar I). Since the agreements are based on capital adequacy, some factors such as size, leverage, and connection are ignored. Later, the Basel III agreement was made to address the problems associated with systemic risks. Basel III also proposes a capital surcharge for Systemically Important Financial Institutions (SIFIs). 
institution's idiosyncratic risk can drive systemic risk, micro-prudential policy is essential to minimizing it. Therefore, a study on systemic risk determinants is useful to developing sound policies.

This paper examines the determinants of systemic risk in the Indonesian banking system by employing panel regressions on 16 public commercial banks. The paper uses market and balance sheet data of the 16 banks over the period from 2001Q4 to 2017Q4. We construct four systemic risk measures using the market data. These measures of the systemic risk are VaR (Jorion, 2006), MESh (Acharya, Pedersen, \& Richardson, 2017), MESdcc (Engle, 2002), and LRMES (Acharya, Engle, \& Richardson, 2012). VaR is the standard measure of systemic risk and considers an institution's worst potential loss, without considering other institutions in the system. MES measures the marginal contribution of an institution's risk to the system. LRMES and MES are similar, since they are rooted in Expected Shortfall (ES). Their difference is that MES measures the loss when the market falls below a certain threshold over a given horizon, whereas LRMES simulates the system for a six-month period and uses the most pessimistic scenarios as the crisis scenarios.

We regressed each of the systemic risk measures on bank characteristics, such as size, capital, credit risk, reliance on deposit, and liquidity. We also controlled for macroeconomic variables, such as GDP per capita following Laeven, Ratnovski, \& Tong (2015). We find that both bank size and loan activity are important determinants of the systemic risk of an institution, which is in line with studies conducted by Laeven et al., (2015) and Varotto \& Zhao (2018). For the macroeconomic variables, we find that credit to the private sector is an important determinant of systemic risk. The results are robust across the systemic risk measures, sub-samples, and forecast horizons. The main contribution of this paper is that it considers several measures of systemic risk, whereas the literature typically focuses on one measure. Considering several measures of systemic risk is important because each measure captures different aspects of systemic risk. Hence, our approach is necessary in order to get more precise results. We consider LRMES, which is still rarely used in the literature. In addition to establishing the determinants of systemic risk, our study utilizes the systemic risk measures to rank the institutions.

The remainder of this paper is structured as follows. Section II presents the conceptual framework and reviews the related literature. Section III reviews the systemic risk measurements and outlines the methodology. Section IV presents the results. Section V concludes the paper.

\section{RELATED LITERATURE}

A growing literature examines systemic risk, particularly covering the definition of systemic risk, its measures and its applications. In their study, De Bandt \& Hartmann (2000) analysed the concept of systemic risk. They argued that the definition of systemic risk has two crucial components, namely shocks and propagation mechanism. Based on financial theory, shocks can be idiosyncratic, affecting the health of only a single financial institution, or systemic, affecting the whole economy. Propagation mechanism is the most crucial in the concept of systemic risk. In a simple sense, it is the mechanism through which shocks transmit from one institution to another. In a financial system, the propagation 
happens through environmental exposure or through share of information, which affects trust in the institutions. From a conceptual point of view, this mechanism of shocks transmission can be seen as the system's adjustment to a new equilibrium. In their review, Benoit, Colliard, Hurlin, \& Pe (2017) argued that there are three sources of systemic risk: systemic risk-taking, contagion mechanism, and amplification mechanism. Systemic risk-taking explains an institution's behaviour towards taking a risk, which is significant and similar to or correlated with other institutions. The contagion mechanism is the spill-over effect from one institution to another, whereas the amplification mechanism explains how small shocks build up into a full blown systemic risk.

A second strand of literature focuses on the systemic risk measures. One of the earliest measures of systemic risk is VaR (see Jorion, 2006). VaR estimates possible losses of a financial institution at a given probability. The limitation of this measure is that it only focuses on the risk of an institution as an individual, not as a part of a system. To address this limitation, Adrian \& Brunnermeier (2016) extended VaR by measuring the contribution of an institution's risk to the system using Conditional VaR (CoVaR) and $\triangle \mathrm{CoVaR}$. CoVaR is defined as the value at risk of a financial system conditional on an institution being in distress, while $\triangle \mathrm{CoVaR}$ measures changes in an institution's CoVaR in its distress and median states. Adrian \& Brunnermeier (2016) use quantile regression to estimate the value of $\triangle \mathrm{CoVaR}$ of each institution, since the method is simple. Girardi \& Ergün (2013) then modified the calculation of CoVaR by using Generalized Autoregressive Conditional Heteroskedasticity (GARCH) model. They also changed the definition of the financial distress from being exact to at most at its VaR. By doing so, they were able to consider a more extreme distress event and improve the consistency of the measure.

Apart from VaR, the Expected Shortfall (ES) is a measure of systemic risk that has been substantially developed. The ES is defined as a systemic condition of institutions conditional on the overall system's shortfall. The latest popular measure is the MES proposed by Acharya et al. (2017). This measure is an extension of ES, which explains the marginal contribution of a financial institution to a system. Acharya et al. (2017) extended the MES and creating a new measure, namely Systemic Expected Shortfall (SES), which reveals the tendency of a financial system to be undercapitalized when the system as a whole is undercapitalized. Another extension of MES is Component Expected Shortfall (CES), which was developed by Banulescu, Denisa, \& Dumitrescu (2014). It decomposes the ES, while accounting for the characteristics of the institution, which compensates the shortcoming of the MES. This measure also combines two concepts: the toobig-to-fail and too-interconnected-to-fail. Another extension of the MES, LRMES, proposed by Acharya et al. (2012), measures the expected loss of an institution's equity generated from the simulation of the system's condition in the future-for example, six months into the future. Brownlees \& Engle (2017) also extended the MES measure and introduced SRISK. This measure considers the liabilities and size of the financial institution in the calculation of systemic risk. SRISK measures the capital shortfall of an institution conditional on a severe market decline, which can influence the whole financial system. Brownlees \& Engle (2017) constructed the measure using the Generalized Autoregressive Conditional Heteroskedasticity- 
Dynamic Conditional Correlation (GARCH-DCC) model following Engle (2002) because the model can capture the stylized facts of the data effectively.

Another systemic measure is Distressed Insurance Premium (DIP) proposed by Huang, Zhou, \& Zhu (2011). The concepts of DIP and ES are similar in that both are based on the conditional expectations of portfolio losses under extreme conditions, but their respective definitions of the extreme condition are different. While ES defines the state based on the percentile distribution, DIP employs a given threshold loss of the underlying portfolio to determine the condition. DIP is also closely related to CoVaR in the sense that it focuses on identifying the systemically important institutions and banks' marginal contribution. The CoVaR focuses on the spill-over effect from one bank's failure on the system. In comparison, DIP focuses on the loss of a group of banks restricted on the condition of the system being in distress. Allen, Bali, \& Tang (2012) derived an aggregate systemic risk measure, namely Catastrophic Risk of Financial Firms (CATFIN). This measure is estimated using both VaR and ES methodologies, which are estimated using three distributions: (1) parametric distribution based on Generalized Pareto Distribution (GDP), (2) parametric distribution based on Skewed Generalized Error Distribution (SGED), and (3) nonparametric distribution.

Our paper is related closely to the literature that measures systemic risk and examines determinants of systemic risk for banks. Studies on systemic risk are mainly conducted for US and European banks. For example, Brunnermeier, Dong, \& Palia (2012) studied the systemic risk of a large sample of US banks. They decompose the systemic risk into three components: a tail risk, interconnectedness risk, and exposure risk. They find that systemic risk is related to banks' reliance on non-interest income. Puzanova \& Düllmann (2013) investigated the relationship between bank characteristics and systemic risk. They find that bank capital is a crucial modifier of the connection between size and systemic risk. Laeven, Ratnovski, \& Tong (2015) investigated the relationship between bank characteristics (capital, size, funding, and activities) and systemic risk during the global financial crisis of 2008. They find that the systemic risk is positively related to bank size and negatively related to bank capital. Varotto \& Zhao (2018) find support for this evidence and argue that the size of the firm fundamentally drives systemic risk indicators. This result signifies the problem of too-big-tofail institutions. There are several other variables related to systemic risk, such as lending concentration (Beck \& Jonghe, 2013), interbank exposures (Drehmann \& Tarashev, 2013), institutional environment (Anginer, Demirgüç-kunt, \& Mare, 2018), among others. We follow Laeven et al. (2015) and focus on bank size, capital, and activities as the fundamental determinants of systemic risk.

Prior studies used systemic risk measures to rank financial institutions based on their importance. Castro \& Ferrari (2014) use $\triangle \mathrm{CoVaR}$ to identify and rank the systemically important institutions. Using a sample of 26 large European banks, they show that $\triangle \mathrm{CoVaR}$ and time-variation of $\triangle \mathrm{CoVaR}$ can be used to rank only a few banks. Aside that, they show that accounting for bank characteristics in the $\triangle \mathrm{CoVaR}$ framework may improve the ranking of banks. Benoit, Colletaz, Hurlin, \& Pérignon (2013) used several systemic risk measures to rank the importance of US financial institutions. They discovered that each risk measure identified different Systemically Important Financial Institutions (SIFIs) and the ranks obtained 
from the systemic risk estimations were akin to the ranks from sorting the firms based on the market risk or liabilities. Nucera, Schwaab, Koopman, \& Jan (2016) employed both price-based rankings (VaR, $\triangle \mathrm{CoVaR}$, and MES) and fundamentalbased rankings (Leverage and SRISK), and pooled the systemic risk rankings using principal component analysis. By doing so, they untangle the idiosyncratic part and other signals from the systemic risk rankings. They find that the combined ranking is more stable and less volatile.

Since one of the crucial features of systemic risk is its potential effect on the real economy (Kambhu, Schuermann, \& Stiroh, 2007), there are studies that connect the systemic risk measures to real economic activity. Allen et al. (2012) employed a measure of aggregate systemic risk and forecast the macroeconomic downturns in six months proxied by gross domestic production, industrial production, unemployment rate, the Chicago Fed National Activity Index (CFNAI), and many other macroeconomic variables. They find that their aggregate systemic risk measure is a robust predictor of future economic downturns. Giglio, Kelly, \& Pruitt (2016) evaluated the effect of systemic risk on the real economy. They employed 19 measures of systemic risk and find that the measures certainly incorporated some information regarding the likelihood of future macroeconomic downturns. They even find that the indicators of systemic risk are able to forecast policy decisions.

\section{DATA AND METHODOLOGY}

\section{A. Sample}

Our sample is made up of listed commercial banks in Indonesia over the period of 2001Q4 to 2017Q4. We decided to use these listed banks because the measures of systemic risk are based on equity returns. We excluded Islamic banks since they have different accounting rules. The final sample comprises of 16 banks whose assets represent $71.50 \%$ of total assets of Indonesian commercial banks in 2017. The determinants of the systemic risk consist of several bank characteristics and macroeconomic variables. The frequency of the data is quarterly. The bank characteristics are bank size (natural logarithm of total assets), capital ratio (total equity to total assets), funding source (total deposits to total assets), loan activities (total loans to total assets), and liquidity ratio (total cash to total assets). We obtained the bank data from the balance sheets and income statements of banks' interim reports.

In addition to bank characteristics, we follow Laeven et al. (2015) to uses various macroeconomic indicators. The variables are gross domestic product (GDP) growth (variance of GDP growth) to proxy economic stability, GDP per capita (natural logarithm of GDP per capita) to proxy economic development, and private credit (private credit to GDP) to measure the financial structure. The data for the macroeconomic variables was obtained from Bank Indonesia's website and the Federal Reserve Bank of St. Louis Economic Data website. The list of variables and their calculations is presented in Appendix A. To calculate the idiosyncratic and systemic risk measures, we use daily stock price data of the banks, which we obtained from The Indonesia Capital Market Institute (TICMI). 


\section{B. Systemic Risk Measures}

We measured systemic risk using VaR, MES, and LRMES. VaR is one of the earliest measures of systemic risk. The idea of $\mathrm{VaR}$ is to estimate the maximum value of an institution's loss in a given period within a confidence level. We calculated the measure following Jorion (2006) as:

$$
\operatorname{Pr}\left(X_{i} \leq \operatorname{VaR}_{t}^{\alpha}\right)=\alpha
$$

where $X_{i}$ is the equity return of bank $i$ and (1- $\left.\alpha\right)$ is the confidence level. A higher value of VaR indicates a high level of a bank's systemic risk.

Another measure is the extension of ES, which proxies the crisis in the financial system using the aggregate loss. ES uses the condition that the equity return of a bank exceeds a given threshold to define systemic risk. The formula is as follows:

$$
\begin{aligned}
& E S(C)=-E[R \mid R \leq C] \\
& E S_{\alpha}=-E\left[R \mid R \leq-V_{a} R_{\alpha}\right]
\end{aligned}
$$

where $\mathrm{R}$ is the return of a portfolio and $C$ is the given threshold, which is usually based on the VaR level. We can decompose the portfolio return into the sum of each bank's contribution $\left(r_{i}\right)$ with their proportional weights $\left(y_{i}\right)$ as presented in the equation below:

$$
R=\sum_{i=1}^{N} y_{i} r_{i}
$$

Therefore, we can write the ES in terms of banks' weight as follows:

$$
E S_{\alpha}=-\sum_{i=1}^{N} y_{i} E\left[r_{i} \mid R \leq-V a R_{\alpha}\right]
$$

One of the extensions of ES is MES as proposed by Acharya et al. (2017), which measures the contribution of each bank to the extreme value of the market return. MES also shows the sensitivity of market risk to each bank. The formula is as follows:

$$
M E S_{\alpha}^{i}=\frac{d E S_{\alpha}}{d y_{i}}=-E\left[r_{i} \mid R \leq-V a R_{\alpha}\right]
$$

where $M E S_{\alpha}{ }^{i}$ is bank $i$ 's MES with confidence 1- $\alpha$. This means that MES measures the risk of each bank to the system. A high value of $M E S$ indicates a high 
contribution of a bank's risk to the system. There are several ways to estimate MES: (i) the first is by using historical data (MESH); (ii) the second is by using GARCH-DCC as proposed by Engle (2002); (iii) and the last is by using copula approaches following Jiang \& Long (2018).

We also used the LRMES measure of systemic risk, which is the long-run MES. The LRMES measures the expectation of a financial institution's equity conditional on the systemic event, which can be written as:

$$
L R M E S_{i t}=-E_{t}\left[R_{i t+1: t+h} \mid R_{m t+1: t+h}<-V a R_{\alpha}\right]
$$

where $R_{i t+1: t+h}$ is the multiperiod arithmetic equity returns from period $t+1$ until $t+h$. This measure is then approximated by Acharya et al., (2012) using daily MES as follows:

$$
L R M E S_{i t} \approx 1-\exp \left(18 \times M E S_{i t}\right)
$$

This measures a bank's future expected loss.

\section{Empirical Specifications}

To understand the determinants of systemic and idiosyncratic risks in Indonesian banks, we regress systemic and idiosyncratic risks on bank characteristics and macroeconomic variables as follows:

$$
y_{i t+h}=\alpha_{i}+\beta B C_{i t}+\gamma M_{i t}+\varepsilon_{i t+1}
$$

where $y_{i t+h}$ is the risk associated with bank $i$ at time- $t+h$, namely idiosyncratic risk (return) and systemic risk (VaR, MESH, MESdcc, and LRMES). $B C_{i t}$ is a vector of bank characteristics at time $t$, and $M_{i t}$ is a vector of macroeconomic variables at time $t$. The bank characteristics are bank size (Size), capital ratio (ETA), funding source (DTA), loan activities (LTA), and liquidity ratio (CTA), while the macroeconomic variables are GDP growth (GDPg), GDP per capita (GDPc), and private credit (PRIVCRED). $h$ is the forecast horizon; for the main regression, we used $h=1$ to predict the one-quarter ahead systemic risk.

Since the regression is predictive with $h=1$, the dependent variable uses $t+1$ data from 2002Q1 to 2017Q4, while the independent variable uses the information from 2001Q4 to 2017Q3. We performed the Likelihood Ratio, F-test, and the Hausmann test to determine the best estimator.

\section{EMPIRICAL RESULTS}

\section{A. Summary Statistics}

Since we use a predictive regression, summary statistics for the independent variables are based on data from 2001Q4 to 2017Q3, whereas those for the dependent variables are based on data from 2002Q1 to 2017Q4. Table 1 reports the summary statistics for the independent variables and the risk measures. 
The summary statistics show that the bank characteristics are mainly positive over the sample period, except for capital ratio. The minimum value of the capital ratio is negative over the sample period, which indicates poor performance of the banks during certain quarters or years. For the macroeconomic variables, the variance of GDP growth has a maximum value of 11.4, which is quite large. This indicates a significant change in GDP growth over the sample period. The other macroeconomic variables are quite steady as the difference between their maximum and minimum values is small as compared with that of GDP growth.

Aside these summary statistics, we present the correlation between variables in Table 2. The table shows that some of the bank characteristics are correlated with the systemic risk measures. The liquidity condition is also significantly correlated to the systemic risk measures, except for VaR. The correlation coefficients are low, meaning that multicollinearity should not be a major problem. The table also shows that all of the systemic risk measures are significantly correlated to one another-some highly correlated, and others negligibly correlated. This shows that the different measures of systemic risk capture different aspects of systemic risk.

Table 1.

\section{Descriptive Statistics}

This table presents the descriptive statistics of variables. The variables are: Size, the natural logarithm of total assets; ETA is total equity to total assets; DTA is total deposit to total assets; LTA is total loan to total assets; CTA is total cash to total assets; GDPg is the variance of GDP growth; GDPc is the natural logarithm of GDP per capita; PRIVECRED is the ratio of private credit to GDP; Return is measured in logarithm formula; VaR is the value-at-risk; MESH is MES calculated using historical data; MESdcc is MES calculated using GARCH-DCC; and last LRMES is the long-run MES. The table presents the number of observations, mean, standard deviation, maximum, minimum, and the value in $25^{\text {th }}$ percentile and $75^{\text {th }}$ percentile.

\begin{tabular}{lccccccc}
\hline Variable & Obs & Mean & Std. Dev & Max & Min & P25 & P75 \\
\hline Size & 993 & 17.6244 & 1.7156 & 20.7990 & 12.7939 & 14.1582 & 20.4662 \\
ETA & 993 & 0.1087 & 0.0374 & 0.2984 & -0.1222 & 0.0509 & 0.1942 \\
DTA & 993 & 0.7673 & 0.1052 & 1.1003 & 0.0279 & 0.5850 & 0.8854 \\
LTA & 993 & 0.5600 & 0.1385 & 0.7977 & 0.1147 & 0.2293 & 0.7505 \\
CTA & 993 & 0.0139 & 0.0075 & 0.0504 & 0.0002 & 0.0025 & 0.0300 \\
GDPg & 64 & 1.7866 & 2.6360 & 11.4038 & 0.0245 & 0.4455 & 0.9707 \\
GDPc & 64 & 15.5897 & 0.5659 & 16.3788 & 14.6049 & 15.4241 & 15.9143 \\
PRIVCRED & 64 & 0.3023 & 6.1469 & 0.406 & 0.234 & 0.263 & 0.291 \\
Return & 993 & 0.0122 & 0.1068 & 0.8976 & -0.7016 & -0.1945 & 0.2559 \\
VaR & 993 & 0.0661 & 0.0375 & 0.2793 & 0 & 0.0115 & 0.1441 \\
MESH & 993 & 0.0303 & 0.0333 & 0.1787 & -0.1279 & -0.0208 & 0.1015 \\
MESdcc & 993 & 0.0256 & 0.0205 & 0.1954 & -0.0229 & 0.0005 & 0.0687 \\
LRMES & 993 & 0.7322 & 1.2957 & 32.7035 & -0.3382 & 0.0093 & 2.4464 \\
\hline & & & & & & &
\end{tabular}

\section{B. Systemic Risk}

The systemic risk measures can be used to investigate the systemic importance of the banks. That is, based on the systemic risk measures, we can rank the banks based on their systemic importance. Using the systemic risk measures, we listed the names of the banks with a high level of systemic risk. Table 3 presents the top five banks with the largest systemic risk in the year 2017. 


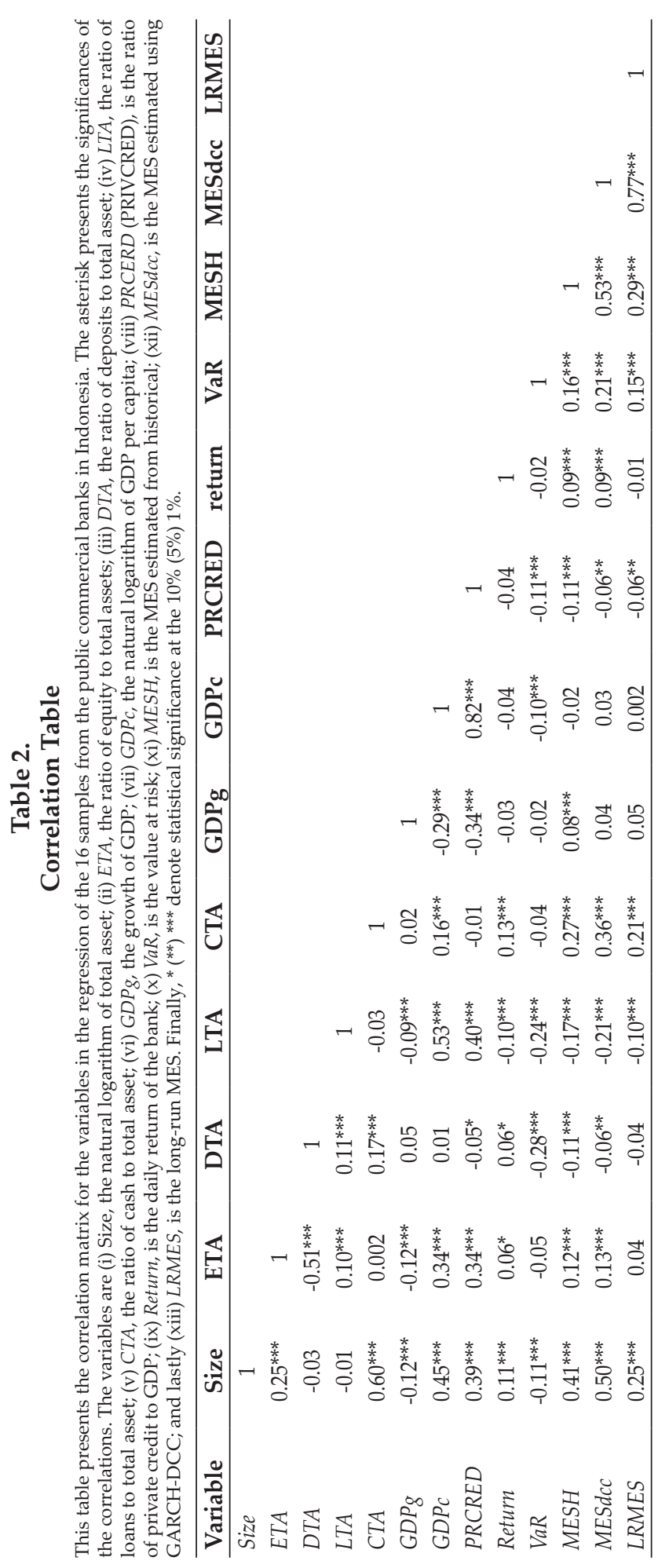


Banks with the largest systemic risk based on VaR, MESH, MESdcc, and LRMES are in Panels A, B, C, and D, respectively. The list of the banks based on VaR and MES measures are significantly different, which highlights how the measures captured different aspects of systemic risk. This result is in line with Nucera et al. (2016) who find that different systemic risk measures signal different messages. This result suggests the need for using more than one measure of the systemic risk, since each measure might only incorporate a different aspect of systemic risk. From the table, it can also be seen that MESdcc and LRMES yielded the same ranking, which indicates that both measures capture the same features of systemic risk.

We can also plot the systemic risk measures in order to see their patterns over the sample period. Figure 1 shows plots of the systemic risk measures. The figure reveals that $\mathrm{VaR}$ and $\mathrm{MESH}$ have a quite similar pattern, especially during the second half of the sample period, while MESdcc and LRMES have a similar pattern during the same period. The magnitude of LRMES is high because it measures the long-run value of MES, which is an accumulation of MES values over a period of time. From the figure, we can see that VaR and MESH are less sensitive than MESdcc and LRMES in detecting a crisis period, which comes from the different aspects of systemic risk they captured. Note that all the measures produce same result between 2008Q1 and 2009Q1 - they all indicated high systemic risk - which happened to be the Global Financial Crisis (GFC). After the GFC period, all the measures show an unstable pattern. They showed ups and downs and another peak in 2011Q3. Towards the end of the sample period, the systemic risk measures showed declining patterns, indicating an improvement in the safety and soundness of the banking system.

Table 3.

Systemic Risk Ranking

This table list the names of five banks with largest systemic risk in terms of VaR, MESH, MESdcc, and LRMES in the period of January 2017 until December 2017.

\begin{tabular}{ll}
\hline Rank & \multicolumn{1}{c}{ Bank } \\
\hline 1 & \multicolumn{1}{c}{ Panel A: Based on VaR measures } \\
2 & PT. Bank Mayapada International Tbk \\
3 & PT. Bank OCBC NISP Tbk \\
4 & PT. Bank Artha Graha International Tbk \\
5 & PT. Bank Mega Tbk \\
\hline 1 & PT. Bank CIMB Niaga Tbk \\
\hline 2 & Panel B: Based on MESH measures \\
3 & PT. Bank Mandiri (Persero) Tbk \\
4 & PT. Bank Rakyat Indonesia (Persero) Tbk \\
5 & PT. Bank Maybank Indonedia Tbk \\
\hline 1 & PT. Bank Danamon Indonesia Tbk \\
2 & PT. Bank Pan Indonesia Tbk \\
\hline
\end{tabular}


Table 3.

Systemic Risk Ranking (Continued)

\begin{tabular}{ll}
\hline Rank & \multicolumn{1}{c}{ Bank } \\
\hline 3 & PT. Bank Pan Indonesia Tbk \\
4 & PT. Bank Negara Indonesia (Persero) Tbk \\
5 & PT. Bank Mandiri (Persero) Tbk \\
\hline \multicolumn{1}{c}{ Panel D: Based on LRMES measures } \\
\hline 1 & PT. Bank Danamon Indonesia Tbk \\
3 & PT. Bank Mega Tbk \\
4 & PT. Bank Pan Indonesia Tbk \\
5 & PT. Bank Negara Indonesia (Persero) Tbk \\
\hline
\end{tabular}

Figure 1.

The Average Value of the Banks' Systemic Risk Measure

The figure plots the average value of banks systemic risk for each measure for the sample period 2002Q1-2017Q1. Panel (a) shows the results of Value-at-Risk $(V a R)$ and Historical Marginal Expected Shortfall (MESH). Panel (b) shows the results of Marginal Expected Shortfall estimated from GARCH-DCC (MESdcc), and Long-run Marginal Expected Shortfall (LRMES).

\section{(a) VaR and MESH}

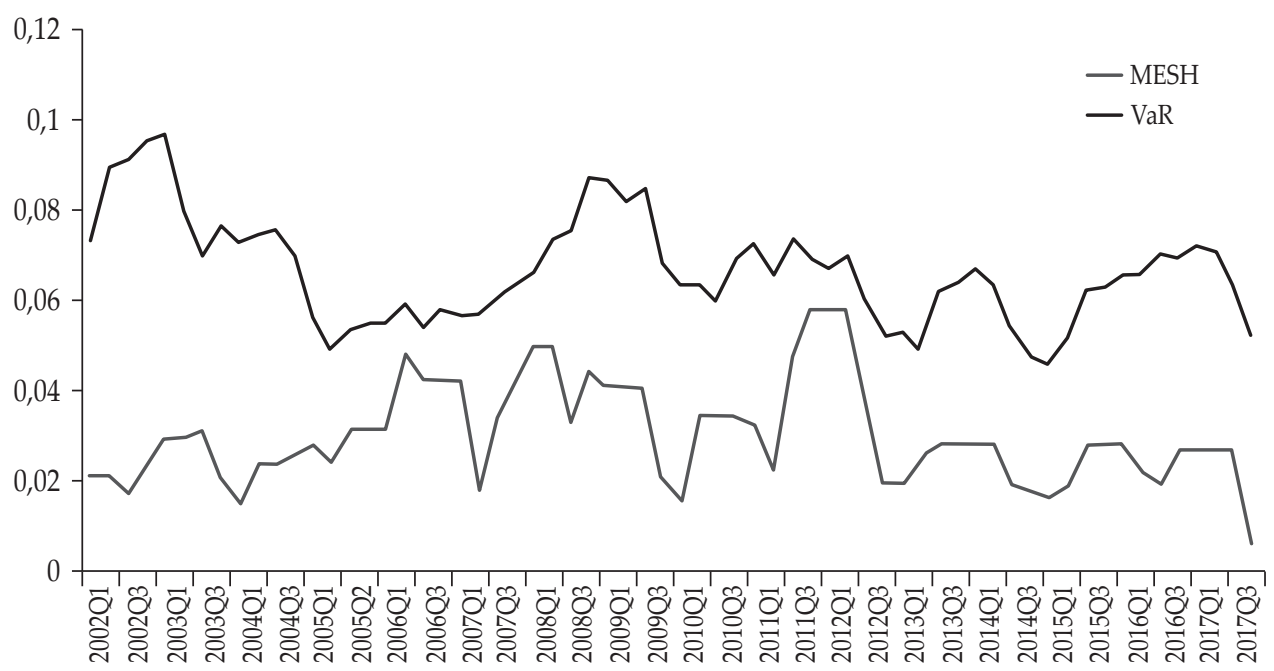


Figure 1.

The Average Value of the Banks' Systemic Risk Measure (Continued)

(b) MESdcc and LRMES $\left(\times 10^{2}\right)$

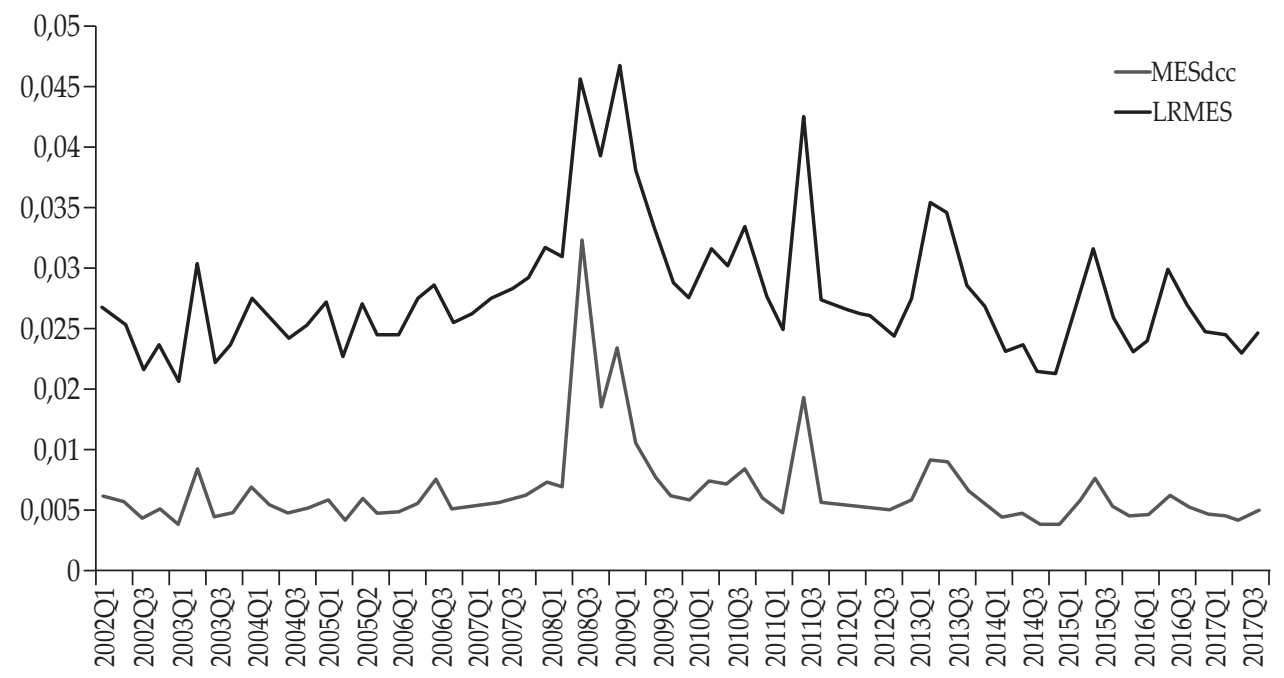

\section{Regression Results}

In this subsection, we present the regression results of all of the risk measures. We use a one-quarter ahead predictive regression, and summarize the results in Table 4. The dependent variables are the risk measures proxied by return, VaR, MESH, MESdcc, and LRMES, while the independent variables are bank characteristics and macroeconomic variables.

The first column of Table 4 shows the determinants of banks' idiosyncratic risk, measured by the stock returns. We find that capital, funding source, credit risk, and liquidity risk are significant predictors of idiosyncratic risk. Their signs indicate that stock return is significantly higher for banks with higher capital, more funding from deposits, fewer loan activities, and less cash. The significance of cash to the stock return might be due to investment activity. More cash means that the bank does not make much investment, which can be seen as lower profitability in the future. This is why the stock return will later on be lower if the present level of cash is high. Column (2) reports the results for VaR as the dependent variable. We find that almost all of the bank characteristics are significant at $1 \%$ level. The results show that higher risk is related to bigger size, lower capital ratio, lower reliance to deposit, lower loan activity, and higher liquidity.

Columns (3) and (4) show the results for the MESH and MESdcc regressions, respectively. Bank size and loan activity are significant in both regressions. Whereas liquidity condition is significant $1 \%$ level in the MESdcc regression, it is not in the MESH regression. By comparing the two MES estimates, it can be seen that the DCC-GARCH approach performs slightly better than the historical approach. Column (5) shows the results for the LRMES regression. These results are consistent with the finding that bank size and liquidity condition are significant 
predictors of systemic risk. The sign of the coefficients suggests that the bigger the size and the higher the liquidity, the higher the systemic risk. We find an interesting result that banks' loan activity is negatively related to systemic risk. This is an anomaly since it contradicts the common belief that loan activity is risky and can lead to non-performing loans.

For the macroeconomic variables, none is a significant predictor of bank return, whereas private credit consistently predicts systemic risk at $1 \%$. The sign of private credit is negative, implying that systemic risk is higher when the credit to the private sector is lower. In addition to private credit, the growth of GDP is weakly significant in the MES historical regression. The remaining macroeconomic variables do not predict systemic risk.

Table 4.

Regression Result

This table presents the result of panel regression for several systemic risk measures. The dependent variables are the systemic risk measures and the independent variables are the bank characteristics and macroeconomic variables. The equation is as follow: $y_{i t+h}=\alpha_{i}+\beta_{1}$ Size $_{i t}+\beta_{2} E T A_{i t}+\beta_{3} D T A_{i t}+\beta_{4} L T A_{i t}+\beta_{5} C T A_{i t}+\gamma_{1} G D P g_{i t}+\gamma_{2} \operatorname{GDPC}_{i t}+\gamma_{3}$ PRIVCRED $i t+\varepsilon_{i t+1}$. Size $=$ the natural logarithm of total asset, ETA = total equity to total assets, DTA = total deposit to total assets, $L T A=$ total loan to total assets, $C T A=$ total cash to total assets, $G D P g=$ variance of GDP growth, $G D P c=$ natural logarithm of GDP per capita, and PRIVCRED = private credit to GDP. The samples are 16 commercial banks in Indonesia. Numbers in parentheses are the t-statistics. Finally, $\left.{ }^{*}{ }^{* * *}\right)^{* * *}$ denote statistical significance at the $10 \%(5 \%) 1 \%$.

\begin{tabular}{lccccc}
\hline Variable & $\begin{array}{c}\text { Return } \\
\mathbf{( 1 )}\end{array}$ & $\begin{array}{c}\text { VaR } \\
\mathbf{( 2 )}\end{array}$ & $\begin{array}{c}\text { MESH } \\
\mathbf{( 3 )}\end{array}$ & $\begin{array}{c}\text { MESdcc } \\
\mathbf{( 4 )}\end{array}$ & $\begin{array}{c}\text { LRMES } \\
\mathbf{( 5 )}\end{array}$ \\
\hline Size & 0.0047 & $0.0178^{* * *}$ & $0.0098^{* * *}$ & $0.0052^{* * *}$ & $0.1678^{* * *}$ \\
& $(1.60)$ & $(4.75)$ & $(5.65)$ & $(4.27)$ & $(2.71)$ \\
ETA & $0.4073^{* * *}$ & $-0.2226^{* * *}$ & 0.0279 & -0.0246 & -1.3541 \\
DTA & $(3.57)$ & $(-5.39)$ & $(0.80)$ & $(-1.29)$ & $(-0.88)$ \\
& $0.1295^{* * *}$ & $-0.1663^{* * *}$ & -0.0076 & 0.0045 & -0.3322 \\
LTA & $(3.35)$ & $(-11.00)$ & $(-0.64)$ & $(0.68)$ & $(-0.64)$ \\
& $-0.0572^{*}$ & $-0.1191^{* * *}$ & $-0.0185^{*}$ & $-0.0162^{* * *}$ & -0.2255 \\
CTA & $(-1.88)$ & $(-9.66)$ & $(-1.77)$ & $(-2.82)$ & $(-0.49)$ \\
& $-0.0572^{*}$ & $0.4576^{*}$ & -0.1921 & $0.2887^{* * *}$ & $18.4402^{* *}$ \\
GDPg & $(1.87)$ & $(1.92)$ & $(-0.97)$ & $(2.64)$ & $(2.12)$ \\
& -0.0031 & -0.0003 & $0.0009^{*}$ & 0.0002 & 0.0211 \\
GDPc & $(-1.51)$ & $(-0.54)$ & $(1.77)$ & $(0.79)$ & $(0.88)$ \\
& -0.0182 & 0.0024 & 0.0058 & 0.0028 & 0.1108 \\
PRIVCRED & $(-1.44)$ & $(0.41)$ & $(1.47)$ & $(1.22)$ & $(0.67)$ \\
& -0.0341 & $-0.1340^{* * *}$ & $-0.1942^{* * *}$ & $-0.0761^{* * *}$ & $-3.2957^{* * *}$ \\
Constant & $(-0.33)$ & $(-4.12)$ & $(-7.02)$ & $(-5.05)$ & $(-2.66)$ \\
& 0.1058 & -0.0309 & $-0.1597^{* * *}$ & $-0.0831^{* * *}$ & -2.7478 \\
Number of observations & $(0.65)$ & $(-0.60)$ & $(-3.59)$ & $(-3.42)$ & $(-1.38)$ \\
Adjusted R-Squared & 993 & 993 & 993 & 993 & 993 \\
Prob(F-stat) & 0.0399 & 0.3491 & 0.0733 & 0.0813 & 0.0256 \\
\hline & 0.000 & 0.000 & 0.000 & 0.000 & 0.000 \\
\hline
\end{tabular}


These results show that bank size is essential when we talk about systemic risk, which in line with studies such as Laeven et al., (2015) and Varotto \& Zhao (2018). Besides, this finding supports the theory of too-big-too-fail, which argues that big banks may act less cautiously in taking risk, since they may get subsidies in case of crisis. For this reason, the government and central bank need to monitor big banks more closely as they have higher systemic risk than small banks. Another point to consider is that regulating credit activity is crucial since credit activity is a significant determinant of banks' systemic risk.

\section{Robustness Checks}

This section shows the results of the robustness tests. Since the size of the bank is considered important, we tested whether the results are not driven by large and small banks. We conducted this robustness test by excluding the five largest and smallest banks in terms of assets. Besides, our results could be driven by the oneperiod forecast horizon. And, hence, the second robustness test aimed to increase the forecast horizon to see the sensitivity of the estimates to the forecast horizon.

The first robustness excluded the five largest and smallest banks, according to the size of total assets in 2017, meaning that only six banks are used in this robustness test. Table 5 presents these results. Consistent with the main regressions, the results show that size, loan activity, and private credit are significant predictors of systemic risk. The signs are also consistent with the main estimates, showing bigger size, and lower loan activity and private credit are related to higher systemic risk. This shows that the results are robust and are neither driven by the big banks nor by the small banks.

In the second robustness test, we test whether the results are driven by the forecast horizon. To do this, we used four-quarter instead of the one-quarter ahead forecast horizon, when predicting systemic risk. The results, which are presented in Table 6, are consistent with the main ones. These results show that size, loan activity, and private credit are significant determinants of systemic risk. The results also show that the performance of the model increased as we increased the forecast horizon. This can be observed by the increasing value of $R^{2}$ of the model. 
Table 5.

\section{Robustness result - Exclude five largest and five smallest banks}

This table presents the result of the first robustness test by employing panel regression for several systemic risk measures. We exclude five largest banks and five smallest banks according to the total asset. The dependent variables are the systemic risk measures and the independent variables are the bank characteristics and macroeconomic variables. The equation is as follow: $y_{i+t h}=\alpha_{i}+\beta_{1}$ Size $_{i+1}+\beta 2 E T A_{i t}+\beta_{3} D T A_{i t}+\beta_{4} L T A_{i t}+\beta_{5} C T A_{i+}+\gamma_{1} G D P g_{i t}+\gamma_{2} G D P c_{i t}+\gamma_{3}$ PRIVCRED $D_{i+}+\varepsilon_{i+1+1}$. Size $=$ the natural logarithm of total asset, ETA = total equity to total assets, DTA = total deposit to total assets, $L T A=$ total loan to total assets, $C T A=$ total cash to total assets, GDPg = variance of GDP growth, GDPC = natural logarithm of GDP per capita, and PRIVCRED = private credit to GDP. The samples are 6 commercial banks in Indonesia. Numbers in parentheses are the t-statistics. Finally, ${ }^{*}\left(^{* *}\right)^{* * *}$ denote statistical significance at the $10 \%(5 \%) 1 \%$.

\begin{tabular}{lcccc}
\hline Variable & VaR & MESH & MESdcc & LRMES \\
& $\mathbf{( 1 )}$ & $\mathbf{( 2 )}$ & $\mathbf{( 3 )}$ & $(\mathbf{4})$ \\
\hline Size & $0.0221^{* *}$ & $0.0241^{* * *}$ & $0.0218^{* * *}$ & $0.6787^{* * *}$ \\
ETA & $(2.58)$ & $(2.57)$ & $(9.56)$ & $(2.76)$ \\
DTA & $-0.1688^{* * *}$ & -0.0321 & $0.0949^{* * *}$ & 1.0702 \\
& $(-2.88)$ & $(-0.50)$ & $(3.11)$ & $(0.33)$ \\
LTA & $0.0625^{* *}$ & -0.0392 & $-0.0362^{* *}$ & -2.0959 \\
& $(2.12)$ & $(-1.21)$ & $(-2.14)$ & $(-1.15)$ \\
CTA & $-0.1803^{* * *}$ & $-0.0488^{* *}$ & $-0.0434^{* * *}$ & -1.0075 \\
& $(-9.63)$ & $(-2.38)$ & $(-4.57)$ & $(-0.99)$ \\
GDPg & $1.2174^{* * *}$ & -0.3828 & $0.3589^{* *}$ & $38.7463^{* *}$ \\
& $(3.66)$ & $(-1.05)$ & $(1.99)$ & $(2.00)$ \\
GDPc & -0.0004 & 0.0007 & 0.0005 & 0.0559 \\
& $(-0.45)$ & $(0.75)$ & $(0.86)$ & $(0.99)$ \\
PRIVCRED & 0.0088 & 0.0007 & $-0.0177^{* * *}$ & -0.6461 \\
& $(0.67)$ & $(0.05)$ & $(-3.85)$ & $(-1.31)$ \\
Constant & $-0.0875^{*}$ & $-0.2871^{* * *}$ & $-0.1213^{* * *}$ & -3.1777 \\
& $(-1.83)$ & $(-5.47)$ & $(-4.17)$ & $(-1.02)$ \\
\hline Number of observations & $-0.3835^{* * *}$ & $-0.2643^{* * *}$ & -0.0228 & 0.8747 \\
Adjusted R-Squared & $(-4.39)$ & $(-2.76)$ & $(-0.46)$ & $(0.17)$ \\
Prob(F-stat) & 384 & 384 & 384 & 384 \\
\hline
\end{tabular}


Table 6.

\section{Robustness result - Forecast horizon}

This table presents the result of the second robustness test by employing panel regression for several systemic risk measures. We increase the forecast horizon to $h=4$ quarters ahead. The dependent variables are the systemic risk measures and the independent variables are the bank characteristics and macroeconomic variables. The equation is as follow: $y_{i t+h}=\alpha+\beta_{1}$ Size $_{i t}+\beta_{2} E T A_{i t}+\beta_{3} D T A_{i t}+\beta_{4} L T A_{i t}+\beta_{5} C T A_{i t}+\gamma_{1} G D P g_{i t}+\gamma_{2} G D P c_{i t}+\gamma_{3}$ PRIVCRED $+\varepsilon_{i t}$. Size $=$ the natural logarithm of total asset, ETA = total equity to total assets, DTA = total deposit to total assets, LTA = total loan to total assets, $C T A=$ total cash to total assets, $G D P g=$ variance of GDP growth, GDPc = natural logarithm of GDP per capita, and PRIVCRED = private credit to GDP. The samples are 16 commercial banks in Indonesia. Numbers in parentheses are the t-statistics. Finally, ${ }^{*}(* *) * * *$ denote statistical significance at the $10 \%(5 \%) 1 \%$.

\begin{tabular}{lcccc}
\hline Variable & $\begin{array}{c}\text { VaR } \\
\mathbf{( 1 )}\end{array}$ & $\begin{array}{c}\text { MESH } \\
\mathbf{( 2 )}\end{array}$ & $\begin{array}{c}\text { MESdcc } \\
\mathbf{( 3 )}\end{array}$ & $\begin{array}{c}\text { LRMES } \\
\mathbf{( 4 )}\end{array}$ \\
\hline Size & $0.0121^{* * *}$ & $0.0094^{* * * *}$ & $0.0050^{* * *}$ & $0.2164^{* * *}$ \\
ETA & $(3.44)$ & $(5.29)$ & $(4.03)$ & $(3.37)$ \\
& $-0.3737^{* * *}$ & 0.0524 & -0.0197 & -1.0437 \\
DTA & $(-9.69)$ & $(1.46)$ & $(-0.99)$ & $(-0.65)$ \\
& $-0.1931^{* * *}$ & 0.0002 & -0.0022 & -0.8094 \\
LTA & $(-13.73)$ & $(0.02)$ & $(-0.33)$ & $(-1.52)$ \\
& $-0.0784^{* * *}$ & $-0.0307^{* * *}$ & $-0.0265^{* * *}$ & $-0.8390^{*}$ \\
CTA & $(-6.74)$ & $(-2.85)$ & $(-4.44)$ & $(-1.74)$ \\
& 0.1539 & $-0.4733^{* *}$ & 0.0426 & 0.7739 \\
GDPg & $(0.67)$ & $(-2.27)$ & $(0.37)$ & $(0.08)$ \\
& 0.0007 & $0.0021^{* * *}$ & $0.0009^{* * *}$ & $0.0607^{* *}$ \\
GDPc & $(1.31)$ & $(3.93)$ & $(3.06)$ & $(2.47)$ \\
& $0.0106^{*}$ & $0.0066^{*}$ & $0.0053^{* *}$ & 0.2435 \\
PRIVCRED & $(1.94)$ & $(1.65)$ & $(2.24)$ & $(1.41)$ \\
& $-0.1193^{* * *}$ & $-0.1948^{* * *}$ & $-0.0864^{* * *}$ & $-4.5066^{* * *}$ \\
Constant & $(-3.98)$ & $(-6.93)$ & $(-5.63)$ & $(-3.52)$ \\
& -0.0486 & $0.1682^{* * *}$ & $-0.1037^{* * *}$ & $-4.5083^{* *}$ \\
Number of observations & $(-1.01)$ & $(-3.69)$ & $(-4.16)$ & $(-2.18)$ \\
Adjusted R-Squared & 945 & 945 & 945 & 945 \\
Prob(F-stat) & 0.3845 & 0.0924 & 0.0798 & 0.0333 \\
& 0.000 & 0.000 & 0.000 & 0.000 \\
\hline
\end{tabular}

\section{CONCLUSION}

Building upon the systemic risk literature, this study investigates the determinants of systemic risk across publicly listed commercial banks in Indonesia. Employing four systemic risk measures, namely VaR, MESH, MESdcc, and LRMES, we show that each measure captures a different aspect of systemic risk. Two measures, MESdcc and LRMES, show a similar pattern over the sample period. This finding emphasizes the importance of using more than one systemic risk measure in order to generate more precise estimates. Despite the fact that each measure captures a different aspect of systemic risk, our results show that their patterns are almost the same. However, the VaR and MESH measures are less sensitive to indicating a crisis than MESdcc and LRMES.

Our study also shows robust evidence that bank size, loan activity, and private credit are significant predictors of banks' systemic risk. Larger banks, and lower loan activity and credit allocated to private sector are related to higher systemic 
risk. The effect of bank size on systemic risk is even stronger in the long run, using the LRMES measure. This result supports the theory that big banks pose excessive systemic risk to the banking system, and thus highlights the need to regulate and to monitor the activities of large banks. The results also indicate the need for the government to control loan activities in the country, since the level of private credit in Indonesia is a significant determinant of banks' systemic risk. An interesting result is that the impact of loan activity on systemic risk is negative, which contradicts the common belief. Therefore, this could be a direction for further research. Future studies could investigate the role of loan activity in bank performance and its impact on systemic risk.

Our study does not establish evidence in support of the too-interconnectedto-fail hypothesis. Even though we find that large banks do have a high systemic risk, we also need to see the connection of the banks in the system since it can be the channelling path for the shock when crisis happens. Therefore, further research should focus on calculating and incorporating, and exploring the interconnectedness of the banking system, since this may create a clear understanding of the contagious paths of the shocks to the system.

\section{REFERENCES}

Acharya, V. V., Engle, R., \& Richardson, M. (2012). Capital Shortfall : A New Approach to Ranking and Regulating Systemic Risks. American Economic Review: Papers \& Proceedings, 102, 59-64.

Acharya, V. V., Pedersen, L. H., \& Richardson, M. (2017). Measuring Systemic Risk. The Review of Financial Studies. https://doi.org/10.1093/rfs/hhw088

Adrian, B. T., \& Brunnermeier, M. K. (2016). CoVaR. American Economic Review, 106, 1705-1741.

Allen, L., Bali, T. G., \& Tang, Y. (2012). Does Systemic Risk in the Financial Sector Predict Future Economic Downturns? The Review of Financial Studies. https:// doi.org/10.1093/rfs/hhs094

Anginer, D., Demirgüç-kunt, A., \& Mare, D. S. (2018). Bank Capital, Institutional Environment and Systemic Stability. Journal of Financial Stability. https://doi. org/10.1016/j.jfs.2018.06.001

Banulescu, G.-, Denisa, \& Dumitrescu, E. (2014). Which are the SIFIs ? A Component Expected Shortfall Approach to Systemic Risk. Journal of Banking and Finance. https://doi.org/10.1016/j.jbankfin.2014.01.037

Beck, T., \& Jonghe, O. De. (2013). Lending Concentration, Bank Performance and Systemic Risk: Exploring Cross-Country Variation. World Bank Policy Research Working Paper No.6604.

Benoit, S., Colletaz, G., Hurlin, C., \& Pérignon, C. (2013). A Theoretical and Empirical Comparison of Systemic Risk Measures. HEC Paris Research Paper No. FIN-2014-1030.

Benoit, S., Colliard, J., Hurlin, C., \& Pe, C. (2017). Where the Risks Lie : A Survey on Systemic. Review of Finance, 109-152. https://doi.org/10.1093/rof/rfw026

Brownlees, C., \& Engle, R. F. (2017). SRISK : A Conditional Capital Shortfall Measure of Systemic Risk. The Review of Financial Studies. https://doi.org/10.1093/rfs/ hhw060 
Brunnermeier, M. K., Dong, G., \& Palia, D. (2012). Banks ' Non-Interest Income and Systemic Risk. In AFA 2012 Chicago Meetings Paper.

Castro, C., \& Ferrari, S. (2014). Measuring and Testing for the Systemically Important Financial Institutions. Journal of Empirical Finance, 25, 1-14. https:// doi.org/10.1016/j.jempfin.2013.10.009

Chan-lau, J. A. (2010). Regulatory Capital Charges for Too-Connected-to-Fail Institutions : A Practical Proposal. IMF Working Paper 10/98.

De-Bandt, O., \& Hartmann, P. (2000). Systemic Risk: A Survey. ECB Working Paper, No. 35, November 2000.

Drehmann, M., \& Tarashev, N. (2013). Measuring The Systemic Importance Of Interconnected Banks. Journal of Financial Intermediation, 22, 586-607. https:// doi.org/10.1016/j.jfi.2013.08.001

Engle, R. (2002). Dynamic Conditional Correlation : A Simple Class of Multivariate Generalized Autoregressive Conditional Heteroskedasticity Models. Journal of Business E Economic Statistics, 20. https://doi.org/10.1198/073500102288618487

Giglio, S., Kelly, B., \& Pruitt, S. (2016). Systemic Risk and the Macroeconomy: An EMpirical Evaluation. Journal of Financial Economics. https://doi.org/10.1016/j. jfineco.2016.01.010

Girardi, G., \& Ergün, A. T. (2013). Systemic Risk Measurement: Multivariate GARCH Estimation of CoVaR q. Journal of Banking and Finance, 37, 3169-3180. https://doi.org/10.1016/j.jbankfin.2013.02.027

Huang, X., Zhou, H., \& Zhu, H. (2011). Systemic Risk Contributions. Journal of Financial Services Research. https://doi.org/10.1007/s10693-011-0117-8

Jiang, C., \& Long, W. (2018). Does Tail Dependence Make A Difference In the Estimation of Systemic Risk? $\triangle \mathrm{CoVaR}$ and MES. Working Paper.

Jorion, P. (2006). Value at Risk: The New Benchmark for Managing Financial Risk. In NY: McGraw-Hill Professional.

Kambhu, J., Schuermann, T., \& Stiroh, K. J. (2007). Hedge Funds, Financial Intermediation, and Systemic Risk. Economic Policy Review, Fedral Reserve Bank of New York, 13, 1-18.

Laeven, L., Ratnovski, L., \& Tong, H. (2015). Bank Size , Capital, and Systemic Risk : Some International Evidence. Journal of Banking and Finance. https://doi. org/10.1016/j.jbankfin.2015.06.022

Nucera, F., Schwaab, B., Koopman, S. J., \& Jan, S. (2016). The Information In Systemic Risk Rankings. Journal of Empirical Finance. https://doi.org/10.1016/j. jempfin.2016.01.002

Puzanova, N., \& Düllmann, K. (2013). Systemic Risk Contributions : A credit portfolio approach. Journal of Banking and Finance, 37, 1243-1257. https://doi. org/10.1016/j.jbankfin.2012.11.017

Varotto, S., \& Zhao, L. (2018). Systemic Risk and Bank Size. Journal of International Money and Finance, 82, 45-70. https://doi.org/10.1016/j.jimonfin.2017.12.002

Zhou, C. (2010). Are Banks Too Big to Fail ? Measuring Systemic Importance of Financial Institutions. International Journal of Central Banking, 6, 205-250. 


\section{APPENDICES}

\section{Appendix A. List of Variables}

\begin{tabular}{lcc}
\hline Variable & Proxy & Calculation \\
\hline Size & Bank Size & Natural logarithm of Total Assets \\
ETA & Capital & Ratio of Total Equity to Total Assets \\
DTA & Reliance of Funding to deposits & Ratio of Total Deposits to Total Assets \\
LTA & Credit Risk & Ratio of Total Loans to Total Assets \\
CTA & Liquidity Risk & Ratio of Total Cash to Total Assets \\
GDPg & Economic Stability & Variance of GDP Growth \\
GDPc & Economic Development & Natural logarithm of GDP per Capita \\
PRIVCRED & Financial Structure & Ratio of Private credit to GDP \\
Return & Idiosyncratic Risk & Variance of bank stock return \\
\hline
\end{tabular}

